\title{
LEVEs dagskonferanse 2019
}

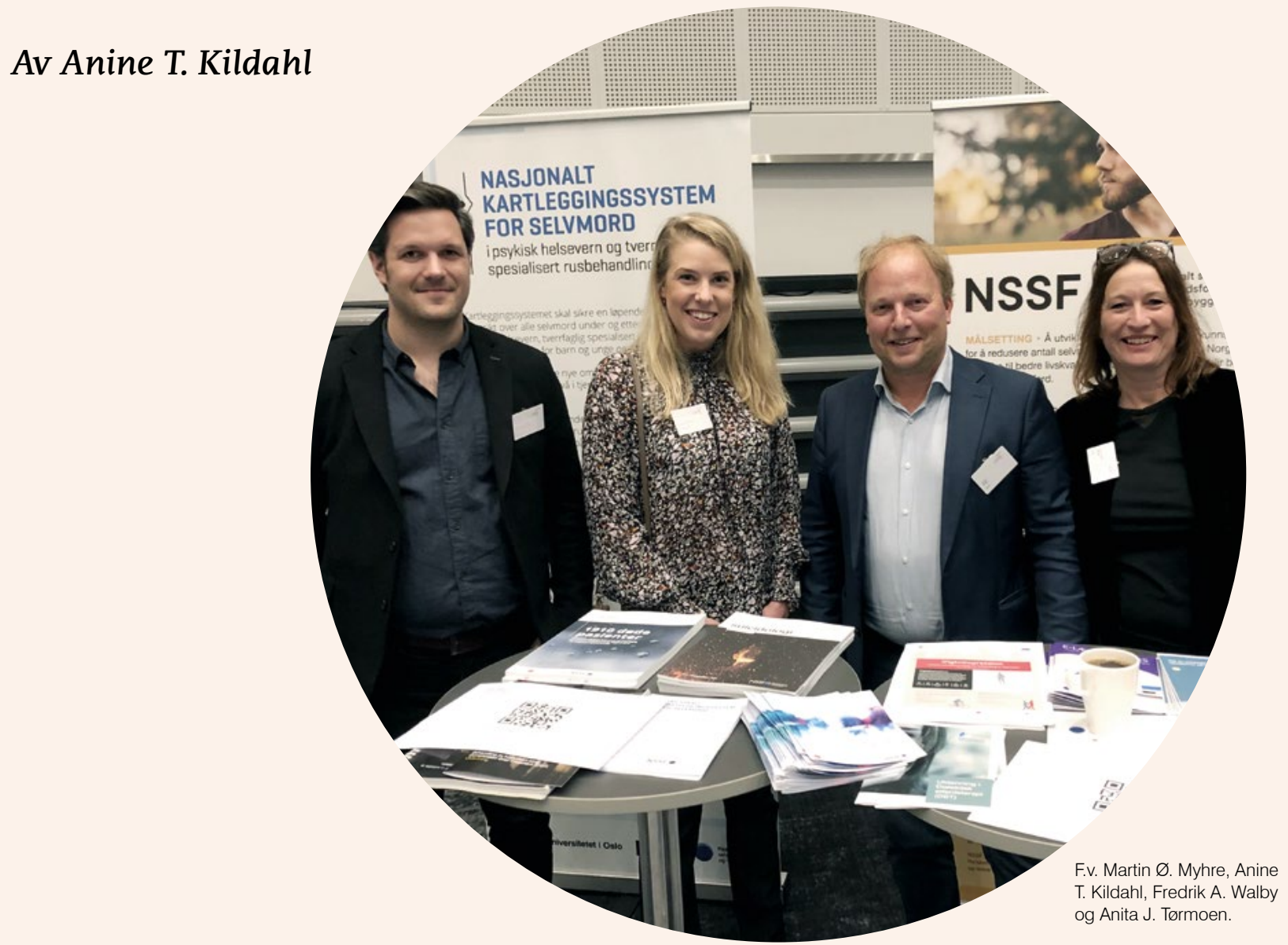

\section{«Snakk om selvmordstanker \\ - det redder liv» var tema for LEVEs årlige nasjonale dagskonferanse som ble arrangert i Stavanger 3. juni med over 100 deltagere.}

LANDSFORENINGEN FOR etterlatte ved selvmord (LEVE) har som formål å støtte etterlatte og berørte ved selvmord og bidra til å forebygge selvmord giennom åpenhet, opplysningsvirksomhet og politisk arbeid. Årets konferanse hadde et vidt spekter av bidrag med alt fra erfaringskunnskap til forskning.

Nasjonalt senter for selvmordsforskning og -forebygging var representert giennom både foredrag og stand under hele dagskonferansen. Førsteamanuensis Anita I. Tørmoen (NSSF) presenterte forskning på selvskading blant unge og delte kunnskap om behandlingsformen Dialektisk atferdsterapi (DBT), mens forsker og psykologspesialist Fredrik Walby (NSSF) foreleste om psykiske lidelser og selvmord. Walby som også er prosjektleder for Nasjonalt kartleggingssystem for selvmord, presenterte funn fra Kartleggingssystemets registerstudie av selvmord blant pasienter i psykisk helsevern og temaet ble videre diskutert i en paneldebatt på slutten av dagen.

Følelsen av skyld og ansvar etter selvmordet var et annet tema som LEVE løftet frem under årets konferanse, hvor Gudrun Austad fra RVTS Vest ledet en samtale med Tove Virata Bråthen (LEVE) og Oddmund Holgersen (LEVE) om deres erfaringer som etterlatte. Dagskonferansen hadde også flere kulturelle bidrag, deriblant sanger ved \#geriljahjerte Silje Sandanger og et humoristisk innslag ved Linda Đye.

Sybille Greiner er leder for LEVE Rogaland hvor årets konferanse ble arrangert. Se www.leve.no for mer informasion. 